\title{
DETERMINAREA NIVELULUI DE REZISTENȚĂ A GENOTIPURILOR CONTRA ATACUL BOLILOR PRINCIPALE A MATERIALULUI GENETIC DE AMELIORARE A CULTURILOR LEGUMINOASE PE FONDURI NATURALE ŞI ARTIFICIALE DE INFECŢIE
}

\author{
Lencauțan $M$. \\ Institutul de Cercetări pentru culturile de Cîmp "Selecția”, municipiul Bălți, \\ Republica Moldova. \\ lemkautanm@gmail.com
}

\begin{abstract}
In the soil and climatic conditions of the Republic of Moldova, legume crops are attacked by a complex of harmful species, which present a danger in decreasing the level of plant productivity. To solve the problem of increasing the level of production, the basic factor is to estimate highly productive varieties (hybrids), adopted under stressful environmental conditions endowed with high levels of resistance to harmful pathogens can later be used in the process of plant improvement as initial genetic material.
\end{abstract}

Key words: legume crops, varieties, resistance, natural and artificial background, initial genetic material.

\section{Introducere}

Plantele culturilor leguminoase au o importanţă economică înaltă, fiind utilizate în alimentaţia animalelor şi în industrie. Boabele au un conţinut ridicat de proteină, aminoacizi esenţiali, cu calităţi excepţionale [1]. Din punct de vedere agrotehnic, aceste specii sunt bune premergătoare; fixează azotul atmosferic; au putere de solubilizare pentru fosfaţi (mazărea), punând la dispoziţia plantelor acest element într-o formă mai accesibilă; au masa vegetativă bogată, ca urmare pot fi utilizate ca îngrăşământ verde. Dar au şi unele dezvantaje, cum ar fi: sunt pretenţioase la condiţiile pedoclimatice; nu suportă temperaturi scăzute, umiditate, arşiţă timp îndelungat; au sensibilitate mare la unele boli [3].

Soluţionarea problemei majorării volumelor de producţie de fitoproteină este destinată şi sarcina de a crea (în complex cu amelioratori) soiuri adaptive la condiţiile pedoclimaterice nestabile, capabile de a forma un nivel de producţie înalt şi în anii cu dezvoltarea epifitotică a maladiilor principale ale culturilor mazăre, soiei şi fasolei [1].

În condiţiile pedoclimaterice a Republicii Moldova soiurile culturilor leguminoase, dotate cu un potenţial genetic de producţie ridicat sunt influenţate de un complex de factori negativi, dintre care atacul $\mathrm{cu}$ patogeni a maladiilor. Bolile culturilor leguminoase pot fi 
provocate de virusuri, bacterii şi ciuperci. În ultimii ani în condiţiile Republicii Moldova cele mai principale (nocive) maladii a culturilor leguminoase şi furajere s-a înregistrat:

la cultura mazării:

- $\quad$ putregaiul rădăcinilor (g.Fusarium spp. şi Botrytis cinerea );

- fãinarea (Erysiphe comunis Grev.f.pisi).

la cultura soia:

- mozaicul soiei (Soiia virus 1);

- $\quad$ arsura bacteriană a soiei (Pseudomonas glycinae);

- $\quad$ arsura pustulară a soiei (Xanthomonas faseoli);

- mana (Peronospora mancshurica);

- $\quad$ putregaiul rădăcinilor (g.Fusarium spp.), Phytophtora soyae, Pytium spp.).

la cultura fasolea:

- $\quad$ arsura comună (Xanthomonas faseoli, sau Pseudomonas faseolicolie);

- mozaicul comun (Virusul marmor phaseoli sau faseoli virus 1) [4].

\section{Materiale şi metode}

În cercetările, realizate în anul 2019, a fost inclusă estimarea colecţiei a materialului genetic a culturilor: mazărea, soia şi fasolea, atît în condiţii pe fondul natural, cît şi pe fondul artificial (provocator) de infecţie. În calitate de material genetic iniţial în cercetările date au servit soiurile şi liniile (material genetic iniţial) create în laboratorul de ameliorare a culturilor leguminoase şi furajere a IP ICCC „Selecţia”.

După selecţionarea genotipurilor şi mostrelor cu rezistenţă înaltă ele se recomandă pentru includerea în procesul de ameliorare a soiurilor noi.

În condiţiile anului 2019, pe ambele fonduri au fost studiate mostrele a culturilor: mazărea, soia şi fasolea din cîmpul culturilor comparative de concurs, create în laboratorul de ameliorare a culturilor leguminoase (total $\mathbf{4 2 2}$ de mostre: 215 mostre pe fondul natural şi 207 mostre pe fondul artificial de infecție), (tabelul1).

Tabelul 1. Volumul de lucru (cantitatea mostrelor)

\begin{tabular}{|c|c|c|}
\hline Cultura & Fondul natural & Fondul artificial \\
\hline $\begin{array}{c}\text { Mazărea } \\
\text { a) Cîmpul culturilor comparative de concurs }\end{array}$ & 72 & 64 \\
\hline $\begin{array}{c}\text { Soia } \\
\text { a) Cîmpul culturilor comparative de concurs }\end{array}$ & 75 & 75 \\
\hline $\begin{array}{c}\text { Fasolea } \\
\text { a) Cîmpul culturilor comparative de concurs }\end{array}$ & 68 & 68 \\
\hline Total & $\mathbf{2 1 5}$ & $\mathbf{2 0 7}$ \\
\hline
\end{tabular}

În condiţii naturale testarea mostrelor la atac cu patogenii a principalelor boli a fost efectuată pe parcelele amplasate pe cîmpurile experimentale a laboratorului de ameliorare a culturilor leguminoase.

Experienţele la culturile leguminoase (pe fondul natural) au fost însamînţate pe data de: mazărea- 13.03.2019 după premergătorul - grâu de toamnă, soia - 26.04.2019 după premergătorul- grâu de toamnă și cultura fasola -03.05.2019, după premergătorul- grâul de toamnă.

Evidenţa nivelului de atac a maladiilor studiate a fost realizată în conformitate cu metodele descrise în : 
1. «Методические указания по изучению устойчивости зерновых и зернобобовых культур к болезням», Л., 1976 г.;

2. «Указатель возбудителей болезней по зернобобовым культурам и гречихе», Л., 1969 г.

În general, condițiile climaterice a anului agricol (2018-2019) au contribuit la dezvoltarea maladiilor la culturile leguminoase: putregaiului rădăcinilor şi făinarea la cultura mazărea, mozaicului, mana şi bacterioza frunzelor şi păstăilor la culturile soia şi fasolea.

Cercetările anului 2019 au inclus 3 experienţe:

\section{Rezultate şi discuții}

Experiența 1 A determina nivelul de rezistență a soiurilor şi liniilor genetice a culturii mazărea la atac cu principalele maladiile pe fonduri naturale şi provocatoare de infecţie.

În anul curent (2019) au fost testate soiurile şi liniile genetice a culturii mazărea (64 de mostre) din cîmpul culturilor comparative de concurs.

Pe fondul provocator semănatul mostrelor a culturii mazărea s-a efectuat în 2 termeni:

- pentru evidențierea nivelului de atac a putregaiului rădăcinilor - 21.03.2019;

- pentru evidenţierea nivelului de atac cu făinarea - 03.06.2019. fonduri.

Afectarea plantelor culturii mazărea cu putregaiul rădăcinilor s-a manifestat pe ambele

Pe fondul natural nivelul de răspîndire a maladiei s-a evidenţiat în limită: de la 7,3\% pînă la $35,4 \%$, iar nivelul de dezvoltare a maladiei: de la $2,3 \%$ pină la $21,4 \%$ (tabelul 2).

Pe fondul artificial (provocator) nivelul de atac a culturii mazărea cu putregaiul rădăcinilor s-a manifestat în limită: de la $15,9 \%$ pînă la $37,9 \%$, iar nivelul de dezvoltare a maladiei: de la 6,3\% pînă la 29,2 la sută (tabelul 2).

Tabelul 2 Rezistența soiurilor și liniilor genetice a culturii mazărea la atac cu patogenii maladiilor în condițiile a.a. 2019 (cîmpul culturilor comparative de concurs)

\begin{tabular}{|c|c|c|c|c|c|c|c|}
\hline \multirow{2}{*}{$\begin{array}{c}\text { \%\% către } \\
\text { numărul } \\
\text { total }\end{array}$} & \multirow{2}{*}{$\begin{array}{c}\text { Cantitatea } \\
\text { de } \\
\text { numere }\end{array}$} & \multirow{2}{*}{$\begin{array}{c}\text { Nivelul de } \\
\text { atac }\end{array}$} & \multirow{2}{*}{$\begin{array}{c}\text { Gradul } \\
\text { de atac } \\
(\%)\end{array}$} & \multicolumn{2}{|c|}{ Fond natural } & \multicolumn{2}{|c|}{ Fond artificial } \\
\hline & & & & $\begin{array}{l}\text { Putregaiul } \\
\text { rădăcinilor }\end{array}$ & Făinareă & $\begin{array}{l}\text { Putregaiul } \\
\text { rădăcinilor }\end{array}$ & Făinareă \\
\hline \multirow{3}{*}{$\begin{array}{c}\text { Cîmpul } \\
\text { culturilor } \\
\text { comparative } \\
\text { de concurs }\end{array}$} & \multirow{3}{*}{$\begin{array}{c}70 \\
\text { (testate } \\
64)\end{array}$} & Rezistente & $<5$ & 53.1 & $\mathbf{0}$ & - & - \\
\hline & & $\begin{array}{c}\text { Slab } \\
\text { rezistente }\end{array}$ & $<10$ & 39.1 & $\mathbf{0}$ & 12.5 & - \\
\hline & & Receptive & $>10$ & 7.8 & $\mathbf{0}$ & 87.5 & 100 \\
\hline
\end{tabular}

Afectarea plantelor cu făinare a fost înregistrată numai pe fondul provocator. S-a constatat, că toate (64 de mostre) testate după caracteristica imunologică se referă la grupa genotipurilor sensibile la atac cu făinarea (cu intensitate 2,7-3 grade). În urma testărilor nivelului de rezistență a soiurulor și liniilor genetice de mazăre la atac cu maladiile în condițiile anului agricol 2019 (fond natural și artificial de infecție) s-au evidențiat cîteva linii genetice care au demonstrat rezistență înaltă la: putregaiul rădăcinilor și făinare (tabelul 3). 
Tabelul 3 Rezultatele testărilor nivelului de rezistență a soiurulor și liniilor genetice de mazăre la atac cu maladiile în condițiile a.a. 2019 (fon natural și artificial de infecție)

\begin{tabular}{|c|c|c|c|c|c|c|c|c|c|}
\hline \multirow{3}{*}{$\begin{array}{l}\mathbf{N} \\
\mathbf{r}\end{array}$} & \multirow{3}{*}{$\begin{array}{c}\text { Denumirea } \\
\text { soiurilor și liniilor }\end{array}$} & \multicolumn{4}{|c|}{ Fond natural } & \multicolumn{4}{|c|}{ Fond artificial } \\
\hline & & \multicolumn{2}{|c|}{$\begin{array}{l}\text { Putregaiul } \\
\text { rădăcinilor }\end{array}$} & \multicolumn{2}{|c|}{ Făinare } & \multicolumn{2}{|c|}{$\begin{array}{l}\text { Putregaiul } \\
\text { rădăcinilor }\end{array}$} & \multicolumn{2}{|c|}{ Făinare } \\
\hline & & $\begin{array}{l}\text { Gradul } \\
\text { de } \\
\text { răspîn } \\
\text { dire }\end{array}$ & $\begin{array}{c}\text { Gradul } \\
\text { de } \\
\text { dezvolt } \\
\text { are } \\
(\%)\end{array}$ & $\begin{array}{l}\text { Gradul } \\
\text { de } \\
\text { răspîn } \\
\text { dire }\end{array}$ & $\begin{array}{c}\text { Gradul } \\
\text { de } \\
\text { dezvolt } \\
\text { are } \\
(\%)\end{array}$ & $\begin{array}{l}\text { Gradul } \\
\text { de } \\
\text { răspîn } \\
\text { dire }\end{array}$ & $\begin{array}{c}\text { Gradul } \\
\text { de } \\
\text { dezvolt } \\
\text { are } \\
(\%)\end{array}$ & $\begin{array}{l}\text { Gradul } \\
\text { de } \\
\text { răspîn } \\
\text { dire }\end{array}$ & $\begin{array}{c}\text { Gradul } \\
\text { de } \\
\text { dezvolt } \\
\text { are } \\
(\%)\end{array}$ \\
\hline 1 & $\begin{array}{c}\text { Gropis } \mathrm{x} \\
\text { Belcovaia grozdi }\end{array}$ & 17,7 & 7,4 & $\mathbf{0}$ & $\mathbf{0}$ & 15,9 & 8,0 & 2,8 & 100 \\
\hline 2 & Fps 261(12-01) & 12,9 & 3,3 & $\mathbf{0}$ & $\mathbf{0}$ & 16,0 & 8,4 & 2,8 & 100 \\
\hline 3 & $\begin{array}{c}\text { Carena } x \\
\text { Belcovaia grozdi } \\
\end{array}$ & 14,7 & 3,7 & $\mathbf{0}$ & $\mathbf{0}$ & 18,8 & 9,5 & 3,0 & 100 \\
\hline 4 & $\begin{array}{l}\text { Dic Trom x x } \\
\text { Carena }\end{array}$ & 22,0 & 9,9 & $\mathbf{0}$ & $\mathbf{0}$ & 16,3 & 6,5 & 2,8 & 100 \\
\hline 5 & Bogotări x nord & 20,1 & 5,9 & $\mathbf{0}$ & $\mathbf{0}$ & 17,8 & 8,4 & 3,0 & 100 \\
\hline 6 & $\begin{array}{c}\text { ((Truj.xD.T.)xFla } \\
\text { gman)x } \\
\text { (Sm.xCom.Fa-le) }\end{array}$ & 14,4 & 7,2 & $\mathbf{0}$ & $\mathbf{0}$ & 18,8 & 9,5 & 2,8 & 100 \\
\hline
\end{tabular}

Experienţa 2 A stabili nivelul de rezistenţă a soiurilor şi liniilor genetice culturii soia la atac cu principalele maladii pe fonduri naturale şi fonduri provocatoare de infecţie.

În anul curent (2019) evaluarea nivelului de rezistenţă a genotipurilor culturii soia a fost realizată pe 2 fonduri: natural şi artificial (provocator).

Pe fondul natural au fost estimate mostrele (total 75 de genotipuri) din cîmpul culturilor comparative de concurs.

Fondul provocator a fost amplasat în sectorul fitopatologic al secţiei protecţia plantelor. Semănatul mostrelor a fost efectuat în două termene:

- pentru înregistrarea bacteriozelor şi manei la cultura soia - 25.04.2019;

- pentru evidențierea mozaicului soiei - 13.05.2019.

În perioada de vegetaţie a culturii soia (fondul natural) toate mostrele (75 de genotipuri) au fost supuse atacului de infecţie a mozaicului soiei cu nivelul de infecţie 1-3 grade (şi nivelul de răspîndire: 52,5-100\%). Nivelul de afectare a plantelor cu intensitate de 11,5 grade a fost înregistrat la $32,0 \%$ de mostre (grupa rezistentă), iar restul mostrelor $(65,3 \%)$ au fost afectate cu intensitate de 1,6-2 grade (grupa cu rezistenţa medie), şi în grupa sensibilă (cu intensitatea 2,5-3 grade) au intrat 4\% de mostre.

Pe fondul provocator simptomele de atac cu mozaicul soiei s-a manifestat la toate mostrele (75 de linii) cu un nivel de intensitate de 1,5-2 grade (răspîndirea maladiei de la $80,0 \%$ pînă la $100 \%$ ). Afectarea plantelor cu nivelul de intensitate de 1,5 grade a fost înregistrată la $10,7 \%$ de mostre ce au intrat în grupa rezistentă, iar 85,3\% de mostre s-au înregistrat la grupa cu rezistența medie (1,6-2 grade), şi 5,3\% se referă la grupa sensibilă (tabelul 4).

În condițiile anului 2019 pe ambele fonduri de infecţie plantele au fost atacate cu arsura bacteriană la un nivel de 1-1,8 grade. Răspîndirea maladiei pe fondul natural a fost înregistrată la nivelul 42,5-70,0\%, iar pe fondul provocator - de la 50,0 pînă la 90,0 la sută.

Pe fondul natural $56,0 \%$ de mostre au fost atacate cu arsura bacteriană cu intensitate de 1-1,5 grade (grupa rezistentă), iar $42,7 \%$ a mostrelor s-au referit la grupa cu rezistenţa medie (1,6-2 grade), iar în grupa a III-a (grupa sensibilă) s-au înregistrat 2,7\% de mostre. 
Pe fondul artificial (provocator) toate mostrele (75 de mostre) au fost afectate cu intensitate de 1-2 grade, iar răspîndirea maladiei a fost mai înaltă (de la 50,0 pînă la 90,0\%). Conform datelor înregistrate în condiţiile anului 2019, simptome de atac cu arsură bacretiană (cu intensitatea de 1-1,5 grade) au fost atacate $67,6 \%$ de mostre, ce se referă la grupa rezistentă, 32,4\% de mostre (cu intensitatea de 1,6-2 grade) ce se înregistrează la grupa cu rezistenţă medie.

În anul curent (2019), la cultura soia (pe ambele fonduri ) au fost înregistrate şi simptome de atac cu mana (perenophoroza) la un nivel scăzut. Plantele au fost atacate cu intensitatea de 1 grad (grupa rezistentă). Raspăndirea maladiei pe fondul natural a fost înregistrată la nivelul de 20,0-80,0\%, iar pe fondul provocator de infecţie de la 13,3\% pînă la 82,7 procente (tabelul 4) .

Tabelul 4 Rezistența soiurilor și liniilor genetice a culturii soia la atac cu patogenii maladiilor în conditiiile a.a. 2019 (cîmpul culturilor comparative de concurs)

\begin{tabular}{|c|c|c|c|c|c|c|c|c|c|}
\hline \multirow{2}{*}{$\begin{array}{l}\text { \%\% către } \\
\text { nr. total } \\
\text { Cîmpul }\end{array}$} & \multirow{2}{*}{$\begin{array}{c}\text { Cantitat } \\
\text { ea de } \\
\text { numere }\end{array}$} & \multirow{2}{*}{$\begin{array}{l}\text { Nivelul } \\
\text { de atac }\end{array}$} & \multirow{2}{*}{$\begin{array}{l}\text { Grad } \\
\text { ul de } \\
\text { atac }\end{array}$} & \multicolumn{3}{|c|}{ Fond natural (\%) } & \multicolumn{3}{|c|}{ Fond artificial(\%) } \\
\hline & & & & $\begin{array}{c}\text { Mozai } \\
\text { ca } \\
\text { comun } \\
\check{a}\end{array}$ & $\begin{array}{c}\text { Arsura } \\
\text { bacteria } \\
\text { nă }\end{array}$ & $\begin{array}{c}\text { Man } \\
\text { a }\end{array}$ & $\begin{array}{c}\text { Mozai } \\
\text { ca } \\
\text { comun } \\
\underset{\mathbf{a}}{\breve{a}}\end{array}$ & $\begin{array}{c}\text { Arsura } \\
\text { bacteria } \\
\text { nă }\end{array}$ & $\begin{array}{c}\text { Man } \\
\text { a }\end{array}$ \\
\hline \multirow{3}{*}{$\begin{array}{c}\text { Cîmpul } \\
\text { culturilor } \\
\text { comparati } \\
\text { ve de } \\
\text { concurs }\end{array}$} & \multirow{3}{*}{75} & $\begin{array}{c}\text { Rezisten } \\
\text { te }\end{array}$ & 1,5 & 32,0 & 56,0 & 20,0 & 10,7 & 67,6 & 13,3 \\
\hline & & $\begin{array}{c}\text { Slab } \\
\text { rezistent } \\
\mathrm{e} \\
\end{array}$ & $1,6-2$ & 65,3 & 42,7 & 80,0 & 85,3 & 32,4 & 82,7 \\
\hline & & $\begin{array}{c}\text { Recepti } \\
\text { ve }\end{array}$ & $2,5-3$ & 4,0 & 2,7 & - & 5,3 & - & - \\
\hline
\end{tabular}

Dezvoltarea maladiei a fost depresată din cauza temperaturilor ridicate şi cantităţilor reduse de precipitaţii atmosferice.

Rezultatele testărilor a soiurulor și liniilor genetice cu nivel înalt de rezistență la cultura soia la atac cu maladiile în condițiile anului 2019 (fon natural și artificial de infecție) sunt prezentate în tabelul 5. 
Tabelul 5 Rezultatele testărilor nivelului de rezistență a soiurulor și liniilor genetice de soia la atac cu maladiile în condițile a.a. 2019 ( fond natural și artificial de infecție)

\begin{tabular}{|c|c|c|c|c|c|c|c|c|c|c|c|c|c|}
\hline \multirow[t]{3}{*}{$\mathrm{Nr}$} & \multirow{3}{*}{$\begin{array}{c}\text { Denumirea } \\
\text { soiurilor și } \\
\text { liniilor }\end{array}$} & \multicolumn{4}{|c|}{ Fond natural } & & & \multicolumn{6}{|c|}{ Fond artificial } \\
\hline & & \multicolumn{2}{|c|}{$\begin{array}{c}\text { Mozaicul } \\
\text { comun }\end{array}$} & \multicolumn{2}{|c|}{$\begin{array}{c}\text { Arsura } \\
\text { bacteriană }\end{array}$} & \multicolumn{2}{|c|}{ Mana } & \multicolumn{2}{|c|}{$\begin{array}{c}\text { Mozaicul } \\
\text { comun }\end{array}$} & \multicolumn{2}{|c|}{$\begin{array}{c}\text { Arsura } \\
\text { bacteriană }\end{array}$} & \multicolumn{2}{|c|}{ Mana } \\
\hline & & 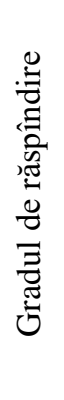 & 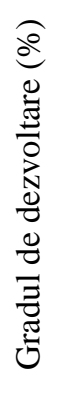 & 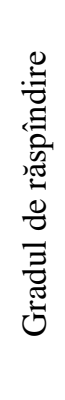 & 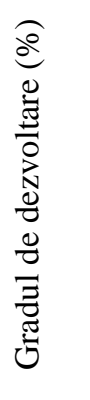 & 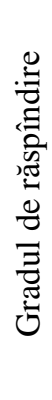 & 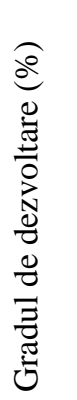 & 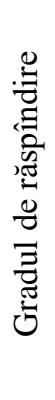 & 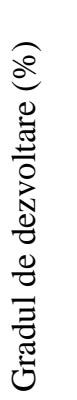 & 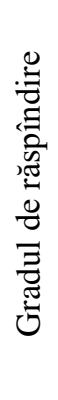 & 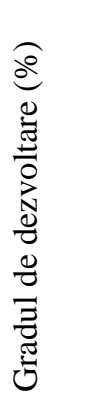 & 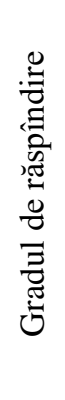 & 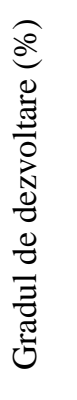 \\
\hline 1 & $\begin{array}{l}\text { Aura } x \\
\text { Colina }\end{array}$ & 1,5 & 92,5 & 1,1 & 55,0 & 1,0 & 20,0 & 1,7 & 80,0 & 1,5 & 66,7 & 1,0 & 20,0 \\
\hline 2 & $\begin{array}{c}\text { Zvelta } x \\
\text { Columna } \\
\end{array}$ & 1,5 & 100 & 1,5 & 42,5 & 1,0 & 11,8 & 1,5 & 95,0 & 1,2 & 65,0 & 1,0 & 10,0 \\
\hline 3 & $\begin{array}{l}\text { N4(china) } x \\
\text { Aura } \\
\end{array}$ & 1,2 & 93,3 & 1,0 & 53,3 & 1,0 & 17,5 & 1,5 & 95,0 & 1,3 & 56,7 & 1,0 & 20,0 \\
\hline 4 & $\begin{array}{c}\text { Belițcaia 90 } x \\
\text { Sonata }\end{array}$ & 1,0 & 100 & 1,2 & 40,0 & 1,0 & 12,5 & 1,5 & 100 & 1,3 & 90,0 & 1,0 & 16,7 \\
\hline 5 & $\begin{array}{c}\text { Harboveanca } \\
\text { x Colina }\end{array}$ & 1,0 & 100 & 1,2 & 46,7 & 1,0 & 11,3 & 1,5 & 100 & 1,5 & 50,0 & 1,0 & 10,0 \\
\hline
\end{tabular}

Experienţa 3 A efectua estimarea fitopatologică a materialului de ameliorare a culturii fasolea la atac cu maladiile principale pe fonduri naturale şi artificiale (provocatoare).

În anul 2019 s-a efectuat estimarea fitopatologică nivelului de rezistenţă a mostrelor de cultura fasole din cîmpul culturilor comparative de concurs (68 de mostre).

În condiţiilor fondului natural evidenţa maladiilor a fost efectuată pe baza parcelelor experimentale a laboratorului de ameliorare a plantelor leguminoase şi furajere.

Pe fondul provocator a laboratorului protecţia plantelor au fost estimate mostrele din cîmpul culturilor comparative de concurs (68 de mostre). $\mathrm{Cu}$ scopul de a colecta infecţia naturală şi a stimula procesul de dezvoltare a patogenilor, semănatul mostrelor de fasole a fost efectuat în doi termeni:

- pentru aprecierea nivelului de atac cu mozaicul comun - 24.04.2019;

- pentru aprecierea nivelului de atac cu arsura comună - 11.05.2019.

În perioada de vegetaţie la cultura fasolea (pe fondul natural) în cîmpul culturilor comparative de concurs s-au manifestat simptomele de atac cu mozaicul comun şi arsura comună.

Toate mostrele (68 de linii) au fost afectate cu mozaicul comun la nivelul de intensitate cu 1-2 grade (nivelul de răspîndire a maladiei: 60,0-100\%). S-a constatat, că 52,9\% de mostre corespund criteriilor grupei rezistente (afectarea plantelor cu intensitatea de 1-1,5 grade), iar restul mostrelor $47,1 \%$ se referă la grupa cu rezistenţă medie (cu intensitatea de 1,6-2 grade) (tabelul 5).

Pe fondul provocator afectarea plantelor cu mozaicul comun s-a demonstrat mai intensiv, pînă la 2,5 grade (răspîndirea maladiei - de la 73,3 pînă la 100\%). Toate (68 de mostre) au fost afectate cu patogenul maladiei. Afectarea plantelor cu intensitate de 1-1,5 
grade a fost înregistrată la $36,8 \%$ de mostre, care prezintă grupa rezistentă, iar restul $(63,2 \%)$ au prezentat grupa cu nivelul de rezistenţa medie, (afectarea plantelor cu intensitatea de 1,62,5 grade) (tabelul 6). Unele parcele pe fondul natural de infecţie au fost afectate mai intensiv decît pe fondul provocator, probabil din cauza condiţiilor meteorologice ridicate şi instabile, cît şi condiţiilor ecologice diverse.

În condiţiile anului agicol 2019, pe perioada de vegetaţie a culturii fasola au fost înregistrate simptomele de atac a maladiei arsura comună a frunzelor și a păstăilor. Pe fondul natural (cîmpul culturilor comparative de concurs) intensitatea afectării plantelor cu arsura comună (bacterioza) a frunzelor a fost înregistrată la nivelul de 2-3 grade (răspîndirea maladiei: 37,5-93,3\%). Afectarea cu această maladie a fost fixată pentru toate 68 de mostre testate, dintre ele: $32,4 \%$ au fost incluse in grupa cu rezistenţă medie (2-2,5 grade), iar 67,6\% de mostre se referă la grupa genotipurilor sensibile (2,6-3 grade). Pe fondul artificial (provocator) afectarea plantelor cu arsura comună a frunzelor a fost mult mai intensivă (de 2,5-3 grade, iar nivelul de răspîndire a maladiei: 60,0-100\%). Dintre toate mostrele testate (68 de linii),numai $26,5 \%$ de mostre se referă la grupa cu rezistenţă medie (2,5 grade), iar restul $73,5 \%$ de mostre intră în grupa cu rezistenţă sesibilă la atac cu bacterioza frunzelor (cu intensitatea de 2,6-3 grade). Afectarea păstăilor plantelor de fasole cu arsura comună a fost înregistrată în condiţiile naturale (cîmpul culturilor comparative de concurs), păstăile au fost afectate cu 1,5-2,5 grade, iar răspîndirea maladiei: 40,0-66,7 procente. Dintre toate 68 de mostre testate, $55,9 \%$ de mostre au fost atacate la nivel de 1,5 grade de intensitate, ce se referă la grupa rezistentă, iar $44,1 \%$ de mostre au prezentat grupa cu rezistenţă medie (cu intensitatea de 1.6-2.5 grade).

Pe fondul provocator $-48,5 \%$ de mostre au intrat în grupa rezistentă (cu intensitate de 1,5 grade), iar 51,5\% de mostre se referă la grupa cu rezistenţă medie (nivelul de intensitate de 1,6-2,5 grade) (tabelul 6).

Tabelul 6. Rezistența soiurilor și liniilor genetice a culturii fasola la atac cu patogenii maladiilor în condițiile a.a. 2019 (cîmpul culturilor comparative de concurs)

\begin{tabular}{|c|c|c|c|c|c|c|c|c|c|}
\hline \multirow[b]{2}{*}{$\begin{array}{r}\% \% \\
\text { către nr. } \\
\text { total } \\
\text { Cîmpul }\end{array}$} & \multirow[b]{2}{*}{$\begin{array}{c}\text { Cantitat } \\
\text { ea de } \\
\text { numere }\end{array}$} & \multirow[b]{2}{*}{$\begin{array}{l}\text { Nivelul } \\
\text { de atac }\end{array}$} & \multirow[b]{2}{*}{$\begin{array}{l}\text { Grad } \\
\text { ul de } \\
\text { atac } \\
(\%)\end{array}$} & \multicolumn{3}{|c|}{ Fond natural } & \multicolumn{3}{|c|}{ Fond artificial } \\
\hline & & & & $\begin{array}{c}\text { Mozai } \\
\text { ca } \\
\text { comu } \\
\text { nă }\end{array}$ & $\begin{array}{c}\text { Arsura } \\
\text { bacteria } \\
\text { nă a } \\
\text { frunzelo } \\
\text { r } \\
\end{array}$ & $\begin{array}{c}\text { Arsura } \\
\text { bacteria } \\
\text { nă a } \\
\text { păstăilo } \\
\text { r } \\
\end{array}$ & $\begin{array}{c}\text { Mozai } \\
\text { ca } \\
\text { comu } \\
\text { nă }\end{array}$ & $\begin{array}{c}\text { Arsura } \\
\text { bacteria } \\
\text { nă a } \\
\text { frunzelo } \\
\text { r } \\
\end{array}$ & $\begin{array}{c}\text { Arsura } \\
\text { bacteria } \\
\text { nă a } \\
\text { păstăilo } \\
\text { r } \\
\end{array}$ \\
\hline \multirow{3}{*}{$\begin{array}{c}\text { Cîmpul } \\
\text { culturilor } \\
\text { comparat } \\
\text { ive de } \\
\text { concurs }\end{array}$} & \multirow{3}{*}{68} & $\begin{array}{l}\text { Reziste } \\
\text { nte }\end{array}$ & 1,5 & 52,9 & 1,5 & 55,9 & 36,8 & - & 48,5 \\
\hline & & $\begin{array}{l}\text { Slab } \\
\text { rezisten } \\
\text { te }\end{array}$ & $1,6-2$ & 47,1 & 22,1 & 41,2 & 63,2 & 26,5 & 45,6 \\
\hline & & $\begin{array}{l}\text { Recepti } \\
\text { ve }\end{array}$ & $2,5-3$ & - & 63,2 & $\overline{4,4}$ & - & 73,5 & 7,4 \\
\hline
\end{tabular}

Rezultatele testărilor nivelului de rezistență a soiurulor și liniilor genetice la cultura fasola la atac cu maladii (fon natural și artificial de infecție) sunt prezentate în tabelul 7. 
Tabelul 7. Rezultatele testărilor nivelului de rezistență a soiurulor și liniilor genetice de fasola la atac cu maladiile în condițiile a.a. 2019 (fon natural și artificial de infecție)

\begin{tabular}{|c|c|c|c|c|c|c|c|c|c|c|c|c|c|}
\hline \multirow[t]{3}{*}{$\mathrm{Nr}$} & \multirow{3}{*}{$\begin{array}{c}\text { Denumirea } \\
\text { soiurilor şi } \\
\text { liniilor }\end{array}$} & \multicolumn{4}{|c|}{ Fond natural } & & & \multicolumn{6}{|c|}{ Fond artificial } \\
\hline & & \multicolumn{2}{|c|}{$\begin{array}{l}\text { Mozaicul } \\
\text { comun }\end{array}$} & \multicolumn{2}{|c|}{$\begin{array}{c}\text { Arsura } \\
\text { bacteriană } \\
\text { a } \\
\text { frunzelor }\end{array}$} & \multicolumn{2}{|c|}{$\begin{array}{c}\text { Arsura } \\
\text { bacteriană } \\
\text { a păstăilor }\end{array}$} & \multicolumn{2}{|c|}{$\begin{array}{l}\text { Mozaicul } \\
\text { comun }\end{array}$} & \multicolumn{2}{|c|}{$\begin{array}{c}\text { Arsura } \\
\text { bacteriană } \\
\mathbf{a} \\
\text { frunzelor }\end{array}$} & \multicolumn{2}{|c|}{$\begin{array}{c}\text { Arsura } \\
\text { bacteriană } \\
\text { a păstăilor }\end{array}$} \\
\hline & & 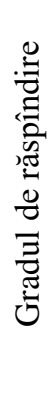 & 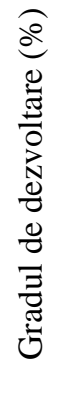 & 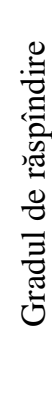 & 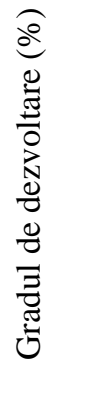 & 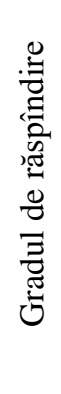 & 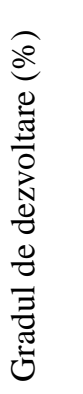 & 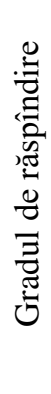 & 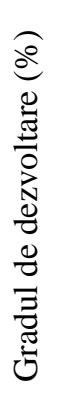 & 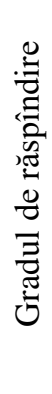 & 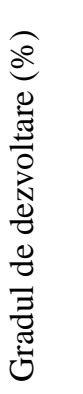 & 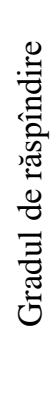 & 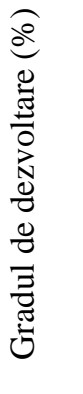 \\
\hline 1 & $\begin{array}{c}\text { Beslet } x \\
\text { Aluna } \\
\end{array}$ & 1,6 & 75,0 & 1,5 & 42,5 & 1,5 & 45,0 & $\mathbf{1 , 8}$ & $\mathbf{7 5 , 0}$ & 2,7 & 76,7 & 1,5 & 53,3 \\
\hline 2 & $\begin{array}{c}\text { Prelom x } \\
\text { D-33-94 } \\
\end{array}$ & 1,3 & 83,3 & 1,5 & 60,0 & 1,5 & 53,3 & $\mathbf{1 , 8}$ & $\mathbf{8 6 , 7}$ & 2,5 & 66,7 & 1,7 & 56,7 \\
\hline 3 & $\begin{array}{c}\text { Astor x } \\
\text { Aluna) } x \\
\text { (Porumb.x } \\
\text { Aur.) } \\
\end{array}$ & 1,5 & $\mathbf{9 5 , 0}$ & 1,5 & 43,3 & 1,8 & 36,7 & 1,5 & 100 & 2,5 & 50,0 & 1,8 & 40,0 \\
\hline 4 & $\begin{array}{c}\text { Lydogorie } x \\
\text { Speranţa }\end{array}$ & $\mathbf{1 , 5}$ & $\mathbf{9 0 , 0}$ & 1,6 & 43,3 & 1,5 & 56,7 & 1,5 & 93,3 & 2,5 & 45,0 & $\mathbf{1 , 5}$ & 60,0 \\
\hline 5 & $\begin{array}{c}\text { Alunax } \\
\text { (Porumb. } \\
\text { xAurorax } \\
\text { Astor) } \\
\end{array}$ & 1,5 & 83,3 & 1,5 & 43,3 & 1,5 & 46,7 & 1,5 & $\mathbf{8 6 , 7}$ & 2,5 & 45,0 & 1,7 & 50,0 \\
\hline
\end{tabular}

\section{Concluzii}

1) În condiţiile anului 2019 la cultura mazărea pe fondul natural, afectarea plantelor cu putregaiul rădăcinilor a fost la un nivel moderat, nivelul de răspîndire s-a evidenţiat în limita de la $7,4 \%$ pînă la $35,4 \%$, iar nivelul de dezvoltare a maladiei de la $2,3 \%$ pînă la 21,4 la sută. Pe fondul artificial putregaiul rădăcinilor s-a manifestat în limită de la $15,9 \%$ pînă la $37,9 \%$, iar nivelul de dezvoltare a maladiei de la $6,3 \%$ pînă la 29,2 la sută. Afectarea mazării cu făinarea a fost înregistrată numai pe fondul provocator la nivelul 2,7-3,0 grade, iar nivelul de răspîndire de 100 procente. Conform datelor înregistrate, toate mostrele sunt sensibile la atac cu făinarea. În condiţiile anului 2019 la cultura mazărea pentru crearea soiurilor noi dotată cu rezistenţa sporită cu gradul de răspîndire de 1.5 se propune utilizarea următoarelor genotipuri : N11 (Gropis x Belcovaia grozdi); N24 (Carena x Belcovaia grozdi ); N39 (D.T x Carena); N51 (Bogotîri x Nord); N54 (Truj x D.T. x Flag.) x Sm. X Com.Fa-le).

2) La cultura soia, pe ambele fonduri s-a înregistrat un nivel de afectare înalt cu mozaicul viral, mana şi bacterioză (1-3 grade). Se recomandă pentru utilizarea în proces de ameliorare a culturii soia cu rezistență sporită cu gradul de răspîndire de la 1-1.5 următoarele 
parcelele: N13 ( Aura x Colina); N59 ( Zvelta x Columna); N71 ( N4 (china x Aura); N72 (Beliţcaia 90 x Sonata); N74 (Harbovianca x Colina)

3) In condiţiile anului 2019, la cultura fasolea pe ambele fonduri s-a evidenţiat o dezvoltare moderată a mozaicului comun (1-2 grade) şi afectarea plantelor cu arsura comună (bacterioza) a fost la un nivel înalt (2-3 grade), iar afectarea păstăilor pe ambele fonduri s-a evidenţiat la un nivel de la (1,5-1,8 grade).În condiţiile anului 2019, la cultura fasolea interes pentru crearea soiurilor noi de fasolă cu rezistenţă la mozaicul comun, arsura comună a frunzelor şi a păstăilor prezintă parcelele: N24 (Beslet x Aluna); N33 (Prelom x D-33-94); N39 (Astor x Aluna) x (Porumb.x Aur.); N46 (Lydogorie x Speranţa); N48 Aluna x (Porumb.x Aurora x Astor).

\section{Bibliografie}

1. В.Ф. Пересыпкин «Сельскохозяйственная фитопатология» Москва. Колос. 1982. ИБН 2722, стр. 128,139, 143;

2. M.Hatman, I.babeș, Al. Lazăr, T.Perju, T. Săpunaru " Protecția plantelor cultivate” București. Ed. Ceres, 1986, pag.102-112.

3. N.Zamfirescu, V.Velican, GH.Valuța, N.Săulescu, F.Cantîr " Fitotehnia II ", București. Ed. Agro-silvică de Stat, 1958, pag. 42-105.

4. I.Lazăr, S.Bădărău, V.Ciobanu, G.Gomoja, C.Lazari, M.Stroiu, A.Furnic “ Boli infecțioase ale culturilor agricole în Republica Moldova,, Chișinău. Cuant, 1999. ISBN 9975 901-190

5. В В Котова «Корневые гнили зернобобовых культур» УДК 632.4:633.35, стр.915.

6. S.Dencescu, E.Miclea, A.Butică. “Cultura soia” București. Ed. Ceres, pag.97-102.

7. «Методические указания по изучению устойчивости зерновых и зернобобовых культур к болезням», Л., 1976;

8. «Указатель возбудителей болезней по зернобобовым культурам и гречихе», Л., 1969. 